\title{
First evidence of scavenging of a Glyptodont (Mammalia, Glyptodontidae) from the Pliocene of the Pampean region (Argentina): taphonomic and paleoecological remarks
}

\author{
Martín de los Reyes, Daniel Poiré, Leopoldo Soibelzon, \\ Alfredo E. Zurita, and M.J. Arrouy
}

\begin{abstract}
The Cingulata Glyptodontidae (Xenarthra) are one of the most conspicuous Cenozoic herbivore clades in South America reaching North America during the Great American Biotic Interchange. The evidence of predation on these large armoured mammals is very scarce and limited to a Pliocene skull (Glyptotherium) in North America and some latest Pleistocene-early Holocene specimens in South America, with signals of human consumption. In this contribution, we present the first case of scavenging on a glyptodont belonging to cf. Eosclerocalyptus lineatus (Hoplophorini) from the Pliocene of the Pampean region (Argentina). In addition, we analyze the potential scavengers and the paleoenvironmental context in which this occurred. The evidence suggests that: a) the carcass was covered by a shallow water body, probably an abandoned channel; b) the carcass was completely covered during a brief lapse of time, probably less than a year; c) the morphology of the bite marks clearly coincide with the dentition of the procyonid Chapalmalania (Mammalia, Procyonidae), thus corroborating some presumptions about the paleoautoecological trends of this taxon.
\end{abstract}

Martín de los Reyes. Facultad de Ciencias Naturales y Museo de La Plata. Paseo del Bosque s/n (1900), La Plata, Buenos Aires, Argentina delossreyes@yahoo.com.ar

Daniel Poiré. CIG de Investigaciones Geológicas, UNLP-CONICET, Calle 1 № 644, 1900 La Plata, Argentina dpoire@gmail.com Leopoldo Soibelzon. División Paleontología de Vertebrados, Facultad de Ciencias Naturales y Museo (UNLP). Paseo del Bosque s/n, 1900, La Plata, Buenos Aires, Argentina Isoibelzon@fcnym.unlp.edu.ar Alfredo E. Zurita. Centro de Ecología Aplicada del Litoral (CECOAL-CONICET) y Universidad Nacional del Nordeste. Ruta 5, km. 2,5, 3400, CC 128 Corrientes, Argentina azurita@cecoal.com.ar M.J. Arrouy. CIG de Investigaciones Geológicas, UNLP-CONICET, Calle 1 № 644, 1900 La Plata, Argentina marouy@gmail.com

Keywords: South America; Glyptodontidae; Procyonidae; Chapalmalania; scavenge; paleoenvironment

PE Article Number: 16.2.15A

Copyright: Palaeontological Association May 2013

Submission: 1 June 2012. Acceptance: 23 May 2013

de los Reyes, Martín, Poiré, Daniel, Soibelzon, Leopoldo, Zurita, Alfredo E. and Arrouy, M.J. 2013. First evidence of scavenging of a Glyptodont (Mammalia, Glyptodontidae) from the Pliocene of the Pampean region (Argentina): taphonomic and paleoecological remarks, Palaeontologia Electronica Vol. 16, Issue 2; 15A; 13p;

palaeo-electronica.org/content/2013/434-scavenging-of-a-glyptodont 


\section{INTRODUCTION}

In this contribution, the first record of scavenging over a glyptodont (Mammalia, Xenarthra, Glyptodontidae) is presented and described. According to the morphological evidence, the material corresponds to the Hoplophorini cf. Eosclerocalyptus lineatus. In addition, we discuss the paleoenvironmental context in which this occurred and the scavenger probably implicated.

During most of the Cenozoic, placental carnivores were absent from South America. The ecological niche of carnivorous and/or scavengers was occupied during most of the Tertiary by several groups, mainly marsupial mammals (Goin, 1995; Forasiepi et al., 2004, 2007), fororracid and teratornitid birds (e.g., Argentavis magnificens; Palmqvist and Vizcaíno, 2003), and cebecid crocodiles (Bona, personal commun.). Among marsupials, the Sparassodonta clade shows clear adaptation to carnivory, especially evident in its dentition (Goin, 1995; Forasiepi et al., 2004). From a biostratigraphic point of view, the first record of the clade corresponds to the Paleocene, while the last record is from the Late Pliocene (Chapadmalalan) (Forasiepi et al., 2009).

Placental carnivores, as well as many other clades of holarctic mammals, arrived in South America during the Great American Biotic Interchange (GABI) (Marshall et al., 1984; Woodburne et al., 2006; Woodburne, 2010). The first record (Late Miocene, Huayquerian) corresponds to Cyonasua (Carnivora, Procyonidae) (Soibelzon and Prevosti, 2012; Soibelzon, 2011). In fact, from their first record and until the Late Pleistocene (Lujanian), procyonids were represented only by two genera: Chapalmalania and Cyonasua (Soibelzon, 2007, 2011).

The second arrival of placental carnivores took place during the Late Pliocene (Vorohuean), when the families Canidae and Mustelidae are first recorded. Finally, the carnivore guild was completed during the Early Pleistocene (Ensenadan) with the record of Felidae, Mephitidae and Ursidae (Soibelzon and Prevosti, 2012).

On the other hand, one of the most conspicuous endemic clades from South America were the glyptodonts (Xenarthra, Glyptodontidae; Late Eocene-Early Holocene; see Mc Kenna and Bell, 1997), a large group of large-sized armored herbivores, in which some terminal Pleistocene taxa reached more than one ton (Alexander et al., 1999). It is evident that the carnivore guild must have preyed on these armored herbivores, but until now the evidence was elusive.
In South America, evidence of predation over glyptodonts is limited to some specimens showing signs of human consumption, during latest Pleistocene-early Holocene (ca. 12-7 ka). Until now, the data are limited to the current territory of Buenos Aires province, Argentina (see Politis et al., 2003; Gutiérrez and Martínez, 2007 and the references therein). Those records correspond mainly to some specimens belonging to the large Glyptodontidae Doedicurus clavicaudatus (Gutierrez and Martínez, 2007).

Thus, there is no evidence of a glyptodont consumed (scavenged or predated) by carnivores in South America until now. The only previous record is represented by a juvenile specimen of Glyptotherium (Glyptodontinae) (F: AM 95737), coming from the late Pliocene of southern USA, in which it is possible to observe the existence of two evident marks in the dorsal area of the skull, certainly produced by a large carnivore (Gillette and Ray, 1981).

\section{MATERIAL AND METHODS}

The biostratigraphic scheme corresponds to that of Cione and Tonni (1999, 2005), whereas the anatomical terminology is based on the contributions of Gillette and Ray (1981) and Zurita (2007). The systematics partially follows Paula Couto (1979), McKenna and Bell (1997) and Fernicola (2008). The terminology used to describe the marks on bones is that of Binford (1981). The dimensions of the tooth marks on the piece Xen30-12 were obtained from a picture taken with a stereoscopic microscope and then measured using the Homies 2006 V2.1 software Hokenn optik Digital.

The marks over the glyptodont bone were compared with one of the only two known skulls of Chapalmalania MLP 54-V-17-1 (holotype of Chapalmalania altifrontis) and MMP-1121-M.

Institutional abbreviations. AMHN (F: $A M)$ : American Museum of Natural History, Frick Collection; MMP: Museo Municipal de Ciencias Naturales de Mar del Plata "Lorenzo Scaglia"; MLP: División Paleontología Vertebrados, Facultad de Ciencias Naturales y Museo, Universidad Nacional de La Plata, Argentina; Xen: Collection "Cementos Avellaneda" Olavarría, Buenos Aires, Argentina.

\section{RESULTS}

Stratigraphic and geographic context. The sediments where Xen-30 was exhumed are located in the intermountain Neogene strata $\left(36^{\circ} 59^{\prime} 8.37^{\prime \prime} \mathrm{S}\right.$ 


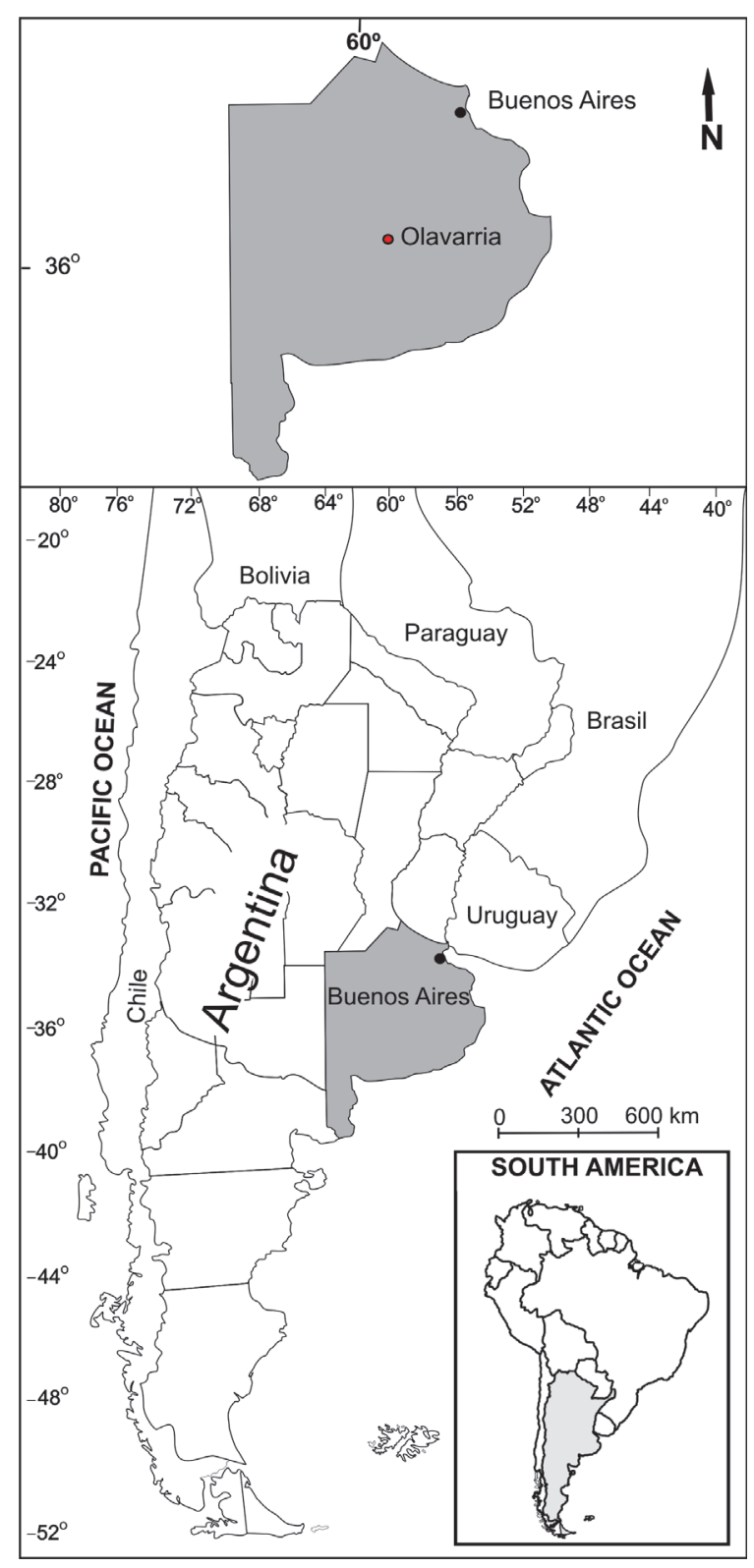

FIGURE 1. Location map showing the locality where Eosclerocalyptus cf. E. lineatus (Xen-30) was exhumed.

$\left.60^{\circ} 13^{\prime} 40.52 " \mathrm{~W}\right)$, belonging to the "Sistema de Tandilia" (Nágera, 1940), near the city of Olavarría, Buenos Aires province, Argentina (Figure 1). The bearing level is included in the "Calera Facies" of the El Polvorín Formation (Poiré et al., 2005, 2007). This geological unit overlaps in discordance to the Loma Negra Formation (Borrelo, 1966) of the Sierras Bayas Group (Dalla Salda and Iñiguez, 1970; Poiré, 1993), and it is covered by the "La Esperanza" Formation (Poiré, 2009).

The "Calera Facies" is composed of lentiform sandstone bodies and massive mudstones with scarce, fine, conglomerate levels. On the other hand, four lenticular sandstone bodies were recognized in the north side of the "Calera Avellaneda" quarry, where the material was exhumed (Figure 2 ). From the base to the top, these bodies are characterized as follows:

Body (A): it reaches up to $6 \mathrm{~m}$ thickness and has a maximum width of $30 \mathrm{~m}$. This level is composed of pink-brownish (dry 7.5YR7/4, humid 7.5YR4/4) well-sorted, silty-sandstone, showing small-scale ( $0.20 \mathrm{~m} \times 0.50 \mathrm{~m}$ average) trough cross-bedding, and bearing a high-frequency vertebrate fossil occurrence. To the top, an isolated, 0-1 m thick, mammelonar calcrete level was recognized.

Body (B): it is visible up to $5 \mathrm{~m}$ thickness and is more than $100 \mathrm{~m}$ wide (limit not visible), composed of silty-sandstone as Body (A) but with mediumscale $(0.2 \mathrm{~m} \times 0.5 \mathrm{~m}$ average) trough cross-bedding, which changes laterally to massive pelites with soil prismatic-texture, manganese-infilled cuttans and bioturbation in galleries of simple tunnels. The glyptodont Xen-30 comes from this level.

Body (C): it consists of a single lentiform megabed (4 $\mathrm{m}$ thickness and $60 \mathrm{~m}$ wide), conformed by a $0.1 \mathrm{~m}$ thick mammeliform carbonate basal level, followed by yellow to pink-brownish (dry 7.5 YR 8/2, humid 10 YR 5/4) fine-grained quarz silt deposits presenting laminar structure. At the top, some restricted lenses $(0.05 \mathrm{~m}$ thick and $0.8 \mathrm{~m}$ wide $)$ of whitish tuff were distinguished.

Body (D): red-brownish, massive clay with prismatic-texture with abundant motes of manganese and scarce mammeliform, discontinued, calcrete levels.

Remarks. The age of this sedimentary sequence ("Cantera Avellaneda") is still poorly known (Prado et al., 1998). Recently, based on the presence of the rodent Phugatherium novum (Hydrochaeridae), Deschamps et al. (2012) suggested that this sequence should be correlated with the Chapadmalal Formation (Chapadmalalan Age/Stage). In addition to the specimen Xen-30, the following taxa were exhumed from Body B: Microtragulus reigi (Argyrolagidae), Phugatherium novum, Promacrauchenia (Machraucheniidae), Eumysops (Echimiydae), Cricetidae indet., Paedotherium cf. typicum (Hegetotheriidae), and Lama (Camelidae). This paleofaunistic assemblage is characteristic of the late Pliocene and, from a biostratigraphic point of view, could be more recent than the Chapadmalalan Age.

From a paleoenvironmental perspective, this sandstone-body is interpreted as the result of the development of a fluvial system of low competence 


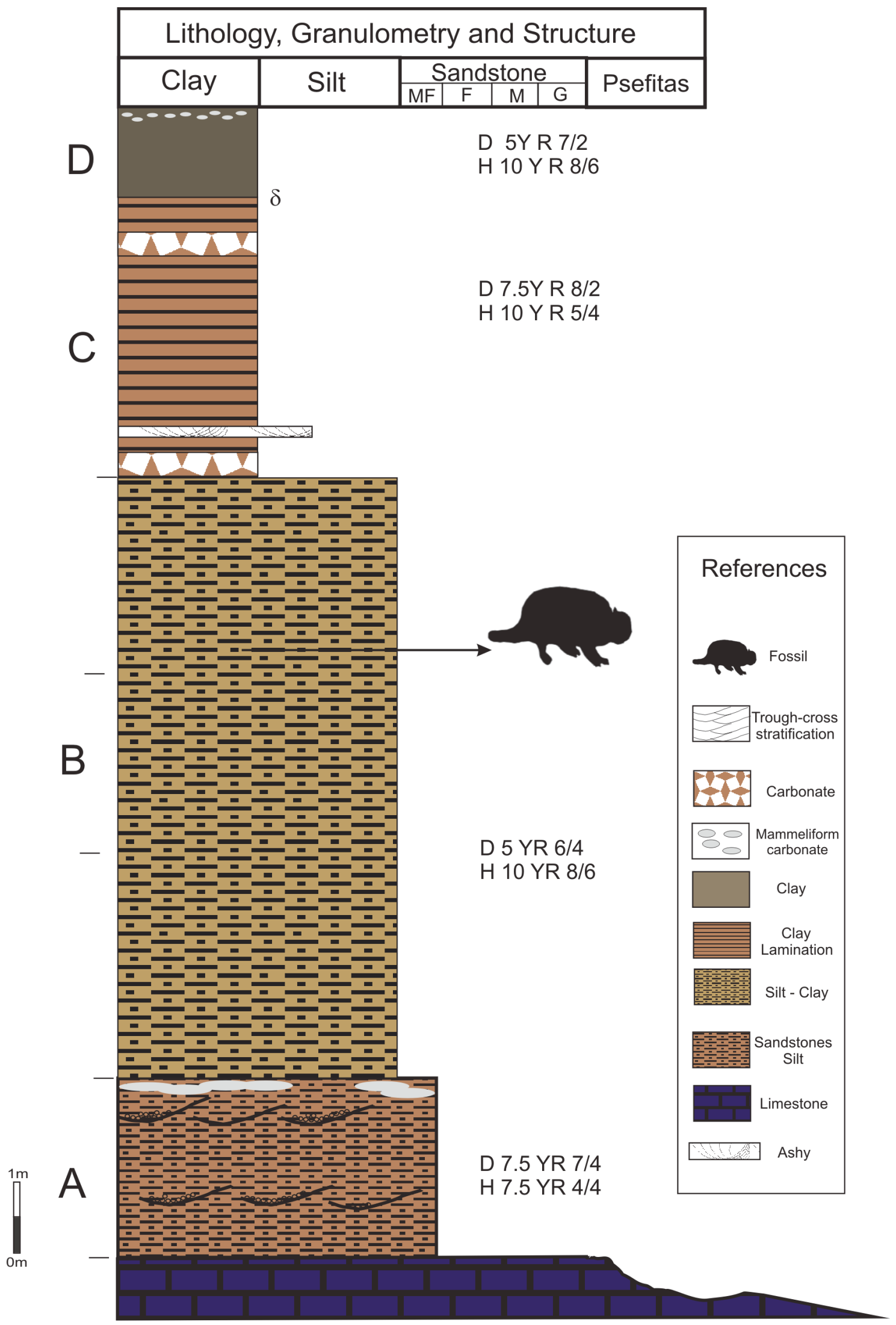

FIGURE 2. Lithostratigraphical profile at the locality where Eosclerocalyptus cf. E. lineatus (Xen-30) was exhumed. 

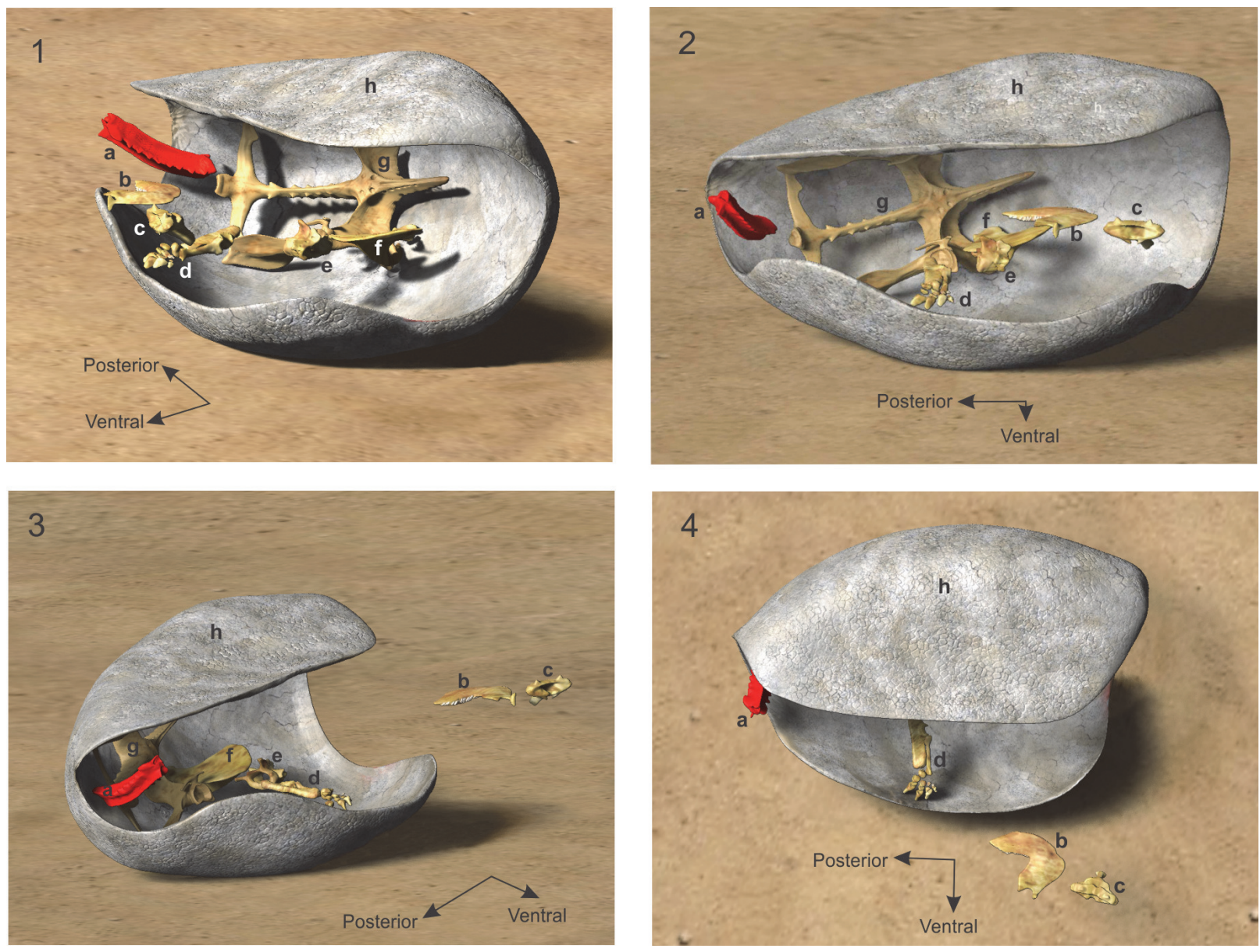

FIGURE 3. 1 to 4: Recreations of the 3D disposition in situ (from four different angles) of Eosclerocalyptus cf. E. lineatus (Xen-30). Abbreviations: a, posterior fused vertebrae; b, right hemimandible; $c$, anterior fused vertebrae; $d$, left zeugopod and autopod; e, atlas and axis; f, scapula; g, synsacrum; h, dorsal carapace.

(sandy), which has left deposited channel facies, abandoned channels and floodplains, including the development of typical plain water bodies (Schumm, 1977; Miall, 1996). The calcretes, the prismatic texture, the cuttans and the bioturbation in galleries are clear evidences of a paedogenesis development under a semiarid paleoenvironment, as suggested by the incipient formation of $B$-calcic horizons, typical of these climates (Alonso-Zarza, 2003).

The fine-grained facies of Body $B$, where the specimen Xen-30 remains were exhumed, are possible to be interpreted as a decantation deposit included in a shallow water body located in an abandoned channel, which was then completely edaphized.

\section{SYSTEMATIC PALEONTOLOGY}

Order CINGULATA Illiger, 1811 Superfamily GLYPTODONTOIDEA Gray, 1869
Subfamily "HOPLOPHORINAE" Huxley, 1864 Tribe HOPLOPHORINI Huxley, 1864

Genus Eosclerocalyptus C. Ameghino, 1919[AUTHOR: none of these ref are listed in the ref section]

Eosclerocalyptus cf. E. lineatus (Ameghino, 1888)

Referred material. Xen-30: dorsal carapace, zeugopod, anterior autopod (articulated), scapula, articulated atlas, axis vertebrae, incomplete synsacrum, part of the cephalic armor, right hemimandible, fragments of ribs, anterior fused vertebrae, posterior fused vertebrae (Figure 3).

Description.The dorsal carapace is $130 \mathrm{~cm}$ long and $140 \mathrm{~cm}$ along the dorsal circumference. The osteoderms that compose the carapace show the typical "rosette" pattern of the Gyptodontidae Hoplophorini. There is a central figure surrounded by one row of peripheral figures (see Zurita, 2007). Like in Eosclerocalyptus lineatus, the exposed surface of the osteoderms is clearly rough, even more 

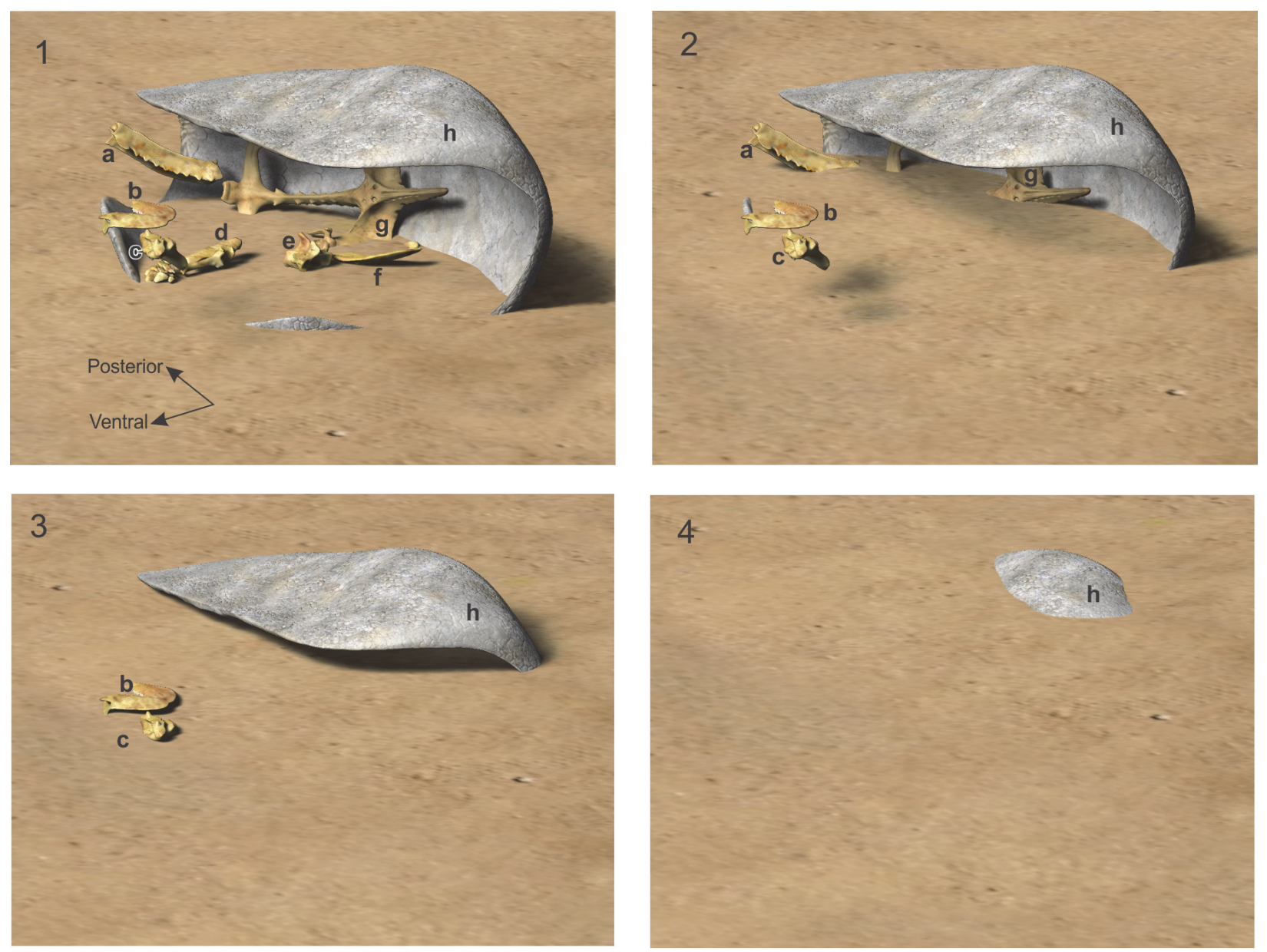

FIGURE 4. Sequence of the four episodes of the burial (numbered from 1 to 4 ) of Eosclerocalyptus cf. E. lineatus (Xen-30). Abbreviations: a, posterior fused vertebrae; b, right hemimandible; c, anterior fused vertebrae; $d$, left zeugopod and autopod; e, atlas and axis; f, scapula; g, synsacrum; h, dorsal carapace.

evident than that observed in the other recognized species of Eosclerocalyptus: E. tapinocephalus and $E$. proximus. In lateral view, it is possible to observe the existence of 38 transversal rows of osteoderms, like in E. lineatus. The dorsal profile is clearly convex, like in E. tapinocephalus, E. proximus and $E$. lineatus, and different from the genus Neosclerocalyptus, in which the dorsal profile is almost completely straight (see Zurita et al., 2009, 2011).

Taphonomy and environment. The evidence shows that, at the time that Xen-30 was buried, the dorsal carapace was lying on its left side (Figure 4.1). As a consequence of this, the ventral opening of the carapace was laterally oriented. Remarkably, the hemimandible, ribs and vertebrae were found outside the dorsal carapace, lying next to the abdominal opening. The other skeletal remains were located within the dorsal carapace.

Bite marks were observed over the neural apophysis of the medium region of the vertebral column. These elements are merged into a single piece articulating above the synsacrum as in every glyptodont (see Gillette and Ray, 1981). This section was found within the carapace, but abnormally located behind the synsacrum (Figure 3 ).

The sediments that filled the carapace are massive although three laminated levels were identified. Carbonates were also observed forming crusts and dolls, but of post depositional formation. The massive levels filled almost all the space inside the carapace, except in those parts where they were interrupted by laminated levels. The most conspicuous laminated level is $5 \mathrm{~cm}$ thick and is located toward the top of the carapace; the next one is $2 \mathrm{~cm}$ thick and is situated below the right pubic ski; finally, the last one is located at the level of the medium line of the synsacrum.

According to the position of the Xen-30 skeletal elements, as well as the sedimentary structures observed within the carapace, it is possible to hypothesize that at least four different events bur- 
ABLE 1. Measurements of the marks $(\mathrm{mm})$ observed in Xen 30-12.

\begin{tabular}{|c|c|c|c|}
\hline Series of marks & Maximum length & Maximum width & ${\text { Area } \mathbf{~ m m}^{\mathbf{2}}}$ \\
\hline $\mathrm{i}$ & 8.67 & 4.38 & 33.93 \\
\hline $\mathrm{ii}$ & 11.07 & 4.32 & 45.56 \\
\hline $\mathrm{iii}$ & 7.98 & 1.95 & 10.92 \\
\hline $\mathrm{iv}$ & 6.97 & 4.63 & 30.98 \\
\hline $\mathrm{v}$ & 8.83 & 1.93 & 13.02 \\
\hline $\mathrm{vi}$ & 7.82 & 2.80 & 17.12 \\
\hline
\end{tabular}

ied the carapace (Figure 4.1-4). The first occurred when the carapace, lying on its left side, suffered a differential entry of sediments that tilted it and filled approximately $40 \%$ of its volume (Figure 4.1 ). This situation can be inferred from the orientation of the laminated levels as well as the final position of the highest part of the skeletal elements. The next episode (Figure 4.2) filled about $65 \%$ of the carapace's volume, covering the skeletal parts that were lying over the laminated sediment first deposited. The only two anatomical elements (hemimandible and thoracic vertebrae) that were found outside the carapace were observed on the top of this last event. The third episode (Figure 4.3) filled $\sim 80 \%$ of the carapace and produced the most conspicuous laminated level. Finally, the carapace was completely covered during the last episode (Figure 4.4).
The disposition of the conserved skeletal elements allows us to infer that they did not suffer a major dispersion respect to their original anatomical position. All preserved remains present a state of weathering 0 of Behrensmeyer (1978), including those that were found outside the dorsal carapace.

Interestingly, Xen-30-12 shows the lack of a semilunar bone section of the neural apophysis (from middle section of the vertebral column) that reaches $30 \mathrm{~mm}$ in diameter. In addition, towards the anterior area of Xen-30-12, immediately below the missed portion, it is possible to observe some small pits and furrows (Table 1) (Figure 5). On the right and left lateral sides of this apophysis, we observed six and three marks, respectively. Most of them are furrows, which are defined as "a wide and linear groove where the thin bone has been removed exposing the underlying spongy tissue"

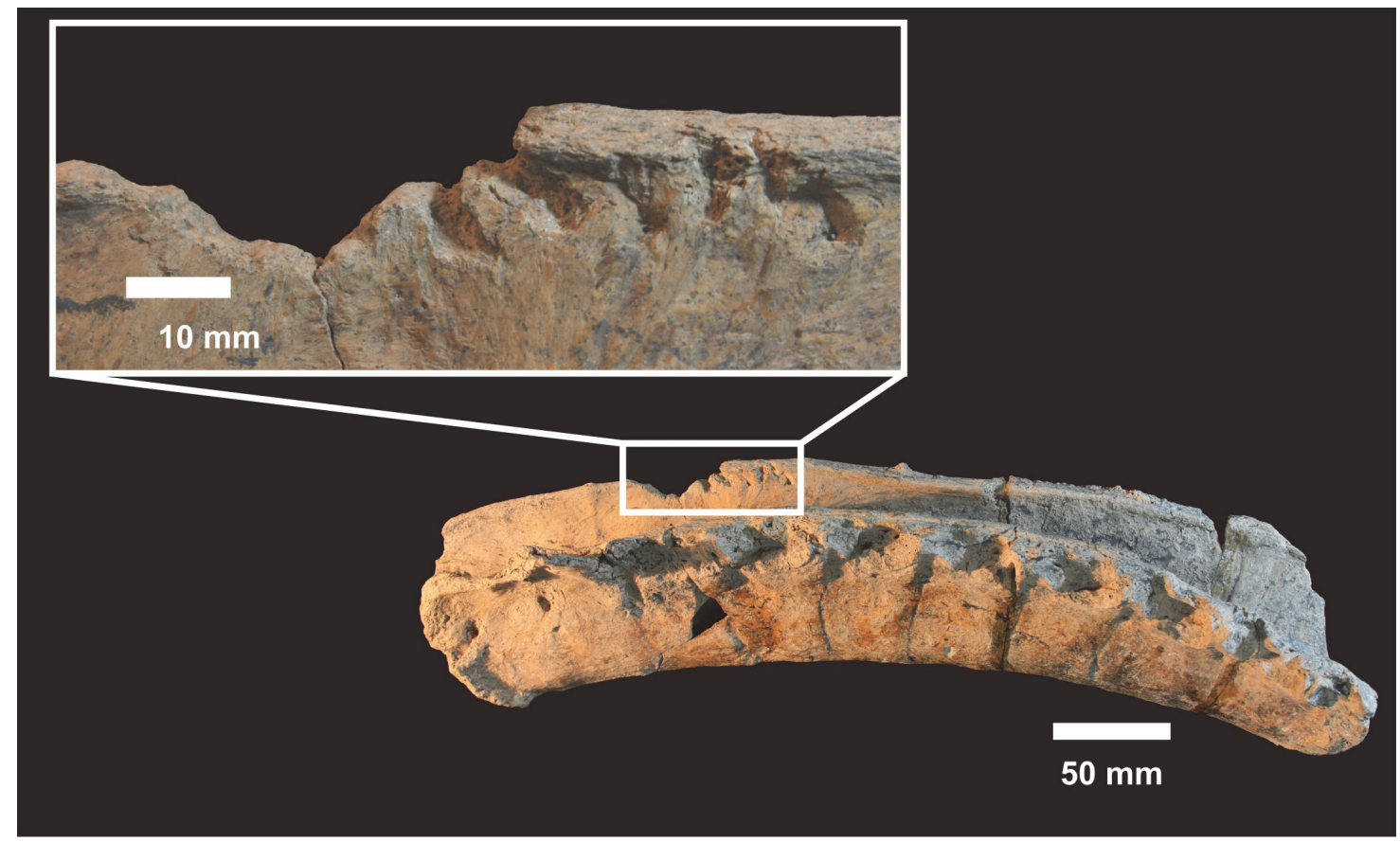

FIGURE 5. Posterior fused vertebrae of Eosclerocalyptus cf. E. lineatus (Xen-30-12) with a detail of the pits and furrows observed on the neural apophysis. 
TABLE 2. Comparative measurements $(\mathrm{mm})$ between the dentition of Chapalmalania altifrontis and the marks observed in Eosclerocalyptus cf. E. lineatus. A. Pair of teeth measured; B. Length between adjacent teeth in MLP 54-V17-1; C. Length between teeth in MMP-1121-M; D. Length between described marks (i to vi, see Figure 6) on Xen 3012. Measurements $B$ and $C$ were taken between the crown apices of selected teeth, measurements $D$ were taken between the centers of adjacent marks.

\begin{tabular}{|c|c|c|c|}
\hline A & B & C & D \\
\hline$|3-| 2 r$ & 11.31 & (i-ii) 13.87 \\
\hline$|2-| 1 r$ & 10.52 & 8.79 & (ii-iii) 7.50 \\
\hline$|1 \mathrm{r}-1|$ & 9.21 & 5.93 & (iii-iv) 7.60 \\
\hline$|1-| 2 \mid$ & 7.18 & 8.17 & (iv-v) 5.55 \\
\hline I2-|3 I & 7.11 & 12.17 & (v-vi) 12.74 \\
\hline Total length & 9.34 & (|3r-|3|) 46.39 & (i-vi) 47.28 \\
\hline
\end{tabular}

(Binford, 1981). Almost all the marks have a shape with predominance of a major axis, where one of the ends is open (neural edge of the apophysis) and the other has a rounded shape (similar to the crown of an incisor). The larger axes of these marks are posteriorly orientated with respect to the sagittal axis. These characteristics, including the size of the missing bone, number and size of the pits and furrows, and the distance between each other, allow us to suggest that they correspond to a single bite. In this scenario, the six marks in one of the lateral areas, and the missing bone may correspond to the six upper incisors and to the canine of a middle-sized eutherian carnivore (Table 2) (Figure 6).
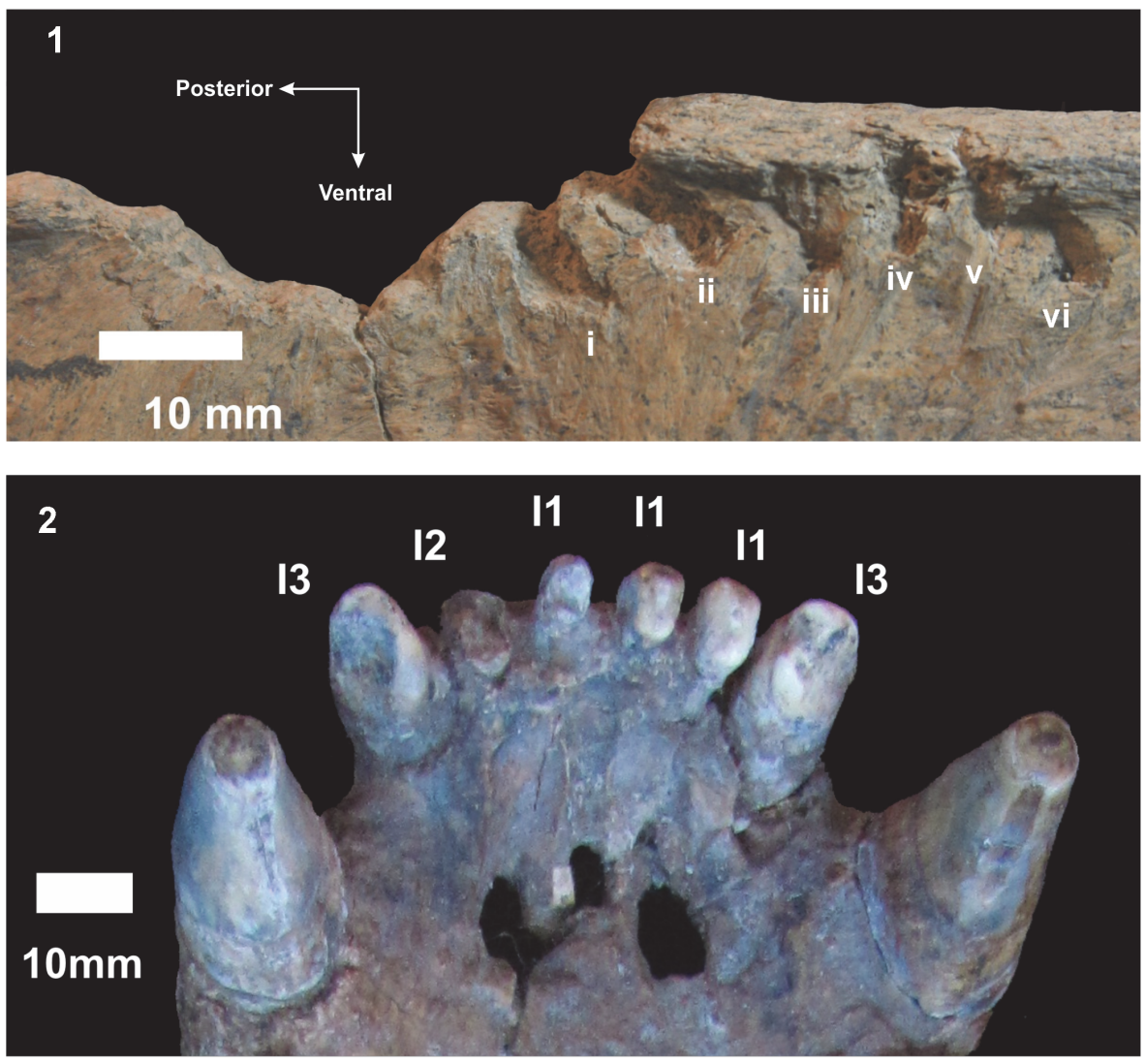

FIGURE 6. 1. Pits and furrows (i to vi) on the neural apophysis of Eosclerocalyptus cf. E. lineatus (Xen-30-12). 2. Palatal view of the rostrum of Capalmalania altifrontis (MMP-1121-M) showing incisors and canines. Abbreviations: 11 first upper incisor, 12 second upper incisor, 13 third upper incisor, $\mathrm{C}$ upper canine. 


\section{DISCUSSION}

During the Chapadmalalan-Barrancalobian lapse (Pliocene ca. 3.5-2.9 Ma), the only known placental carnivores were procyonids. In this context, Cyonasua and Chapalmalania represent two different ecological types; they present very different body sizes and great morphological differences at the skull and dentition (Soibelzon and Prevosti, 2012). Thus, the species of the genus Cyonasua are small to middle sized (body mass $\sim 3$ to $\sim 10$ $\mathrm{Kg}$ ), having a relatively elongated skull compared with that of Chapalmalania; their dentition is bunodont, but showing a greater development of the cutting edges than those seen in Chapalmalania. In this respect, Cyonasua is more likely a raccoon (Procyon). On the other hand, Chapalmalania, due to its larger size $(\sim 25$ to $\sim 30 \mathrm{~kg})$ and dentition, has been compared with bears by several authors (e.g., Kraglievich and de Olazabal, 1959; Bond, 1986; Berman, 1994). In this sense, Berman (1994) suggested that Chapalmalania could be seen as a scavenger.

From our point of view, Chapalmalania is more similar to a hyena than to a bear, since the skull is low, with a well-developed sagittal crest, the zygomatic arches are well separated from the skull, the palatal surface is wide, $\mathrm{P} 1$ to $\mathrm{P} 3$ present only one tall conic and strong cusp (paracone) and a wide subelliptical crown. Furthermore, the ascending ramus of the mandible is high, short and broad, whereas the premolars also have a principal conic and high cusp (protoconid), and the $\mathrm{m} 1$ lacks sharp facets. Finally, hyenas and bears as well as Chapalmalania show a relatively short face. In consequence, we propose that Chapalmalania occupied an omnivorous niche, but having a great aptitude for the consumption of carcasses, especially bones.

Recent studies on marks produced by fossil carnivores over bones based their results mainly on statistical analyses (Selvaggio and Wilder, 2001; Domínguez-Rodrigo and Piqueras, 2003; Delaney-Rivera et al., 2009; Dominato et al., 2011; Saladie et al., 2011). Even so, the taxonomic assignations for the potential agents are generally inaccurate since it is only possible to correlate some marks with the size of the potential carnivore. However, the set of marks and bites described here show a noticeable morphological coincidence with the complete dentition of the specimen MLP 54-V17-1 (holotype of Chapalmalania altifrontis) and MMP-1121-M (Figures 7). An important feature that we observed to taxonomically identify the marks found in the neural apophyses was the distance between each pit and furrow (see Table 2). In this sense, the measurements of the only two known skulls of $C$. altifrontis (MLP 54-V-17-1 and MMP1121-M) show a noticeable similarity in size with those observed in the specimen of Eosclerocalyptus cf. E. lineatus.

Therefore, the morphological evidence suggests that $C$. altifrontis would have consumed carcasses like those described here.

The glyptodont here described was available to be consumed during a long time before the marks under discussion were made (as it could be inferred from the taphonomic and sedimentological study, see above). Therefore, the carcass was not meaty at this time and only some soft tissues remained attached to the bone. In our view, the marks were produced by the scavenger incisors while it pulled the soft tissues, as usually done by bears and hyenas consuming a carcass. We disbelieve that the scavenger was trying to consume the fused vertebras; on the contrary, the marks resulted from the procurement of soft tissues attached to this bone. In this sense, we should consider that the laminar bone at the neural apophyses is very thin and thus susceptible to be easily marked.

Another carnivore present during the Pliocene of the Pampean region was Ahlysictis lelongi (Metatheria, Thylacosmilidae). This marsupial shows a clear adaptation to a hypercarnivore diet: hypertrophy of canines very posteriorly implanted in the skull, reduction in the number of incisive and significant reduction in molar cusps, leaving only the sharp ones (Goin and Pascual, 1989). A. lelongi has morphological features that are not congruent with the marks observed in Xen 30-12, especially when comparing the number and size of incisives with those observed in the marks (Table 1 and 2). Also, due to its hypercarnivore adaptation (see Goin, 1995), it seems unlikely that this species usually consumed carcasses with little soft tissue, as in the case of the glyptodont studied here.

On the other hand, there was no other potential carnivore in South America during the Pliocene that could be responsible for the marks observed.

\section{CONCLUSIONS}

Specimen Xen-30 corresponds to the Glyptodontidae Eosclerocalyptus cf. E. lineatus, which in addition represents the most complete Glyptodontidae for the Chapadmalalan-Marplatan lapse (Pliocene-earliest Pleistocene) in South America. The depositional environment in which cf. E. lineatus was found is interpreted in this contribution as a 

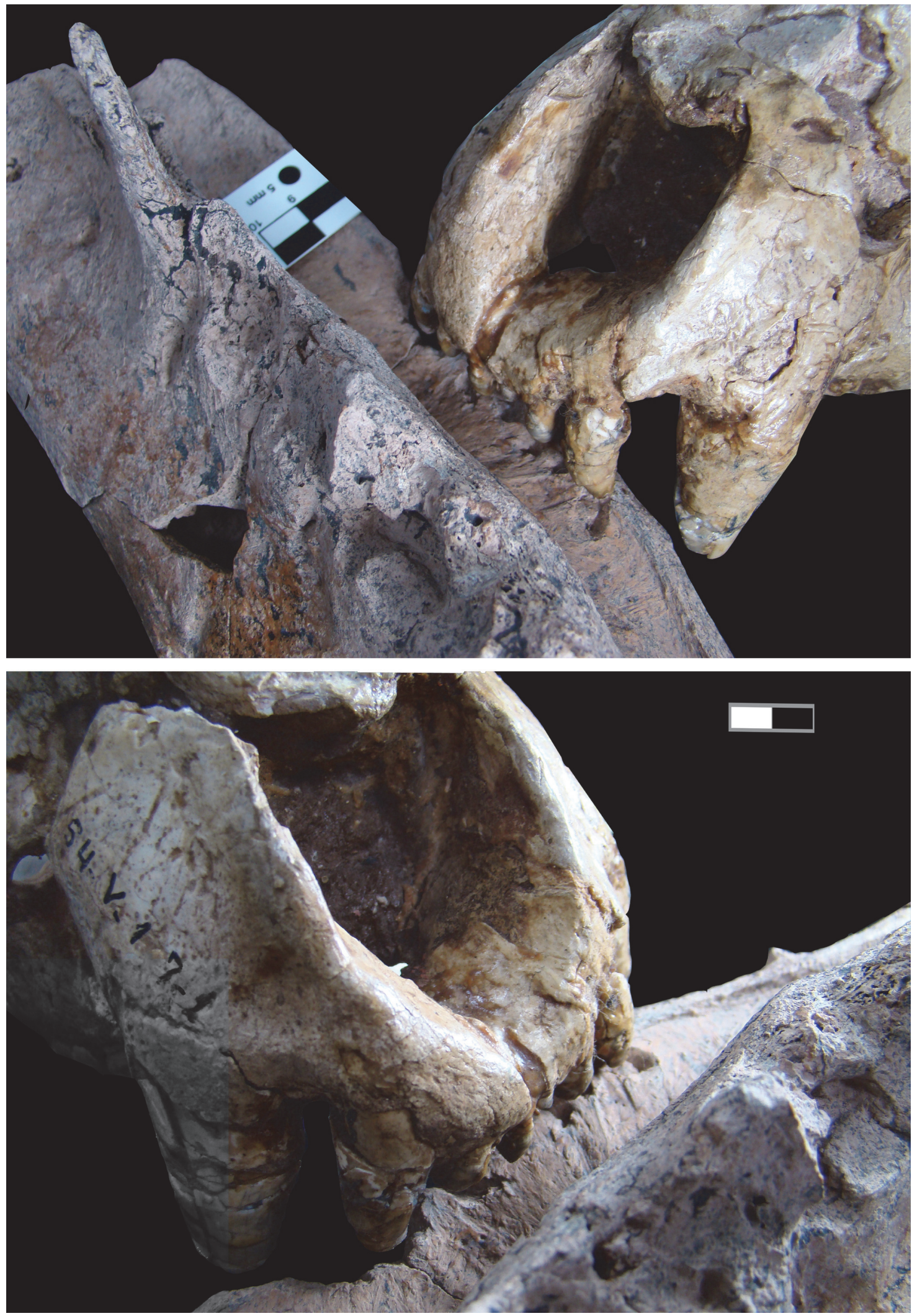

FIGURE 7. Two different views of a combined image of the rostrum of Chapalmalania altifrontis (54-V-17-1) "biting" the posterior vertebrae of Eosclerocalyptus cf. E. lineatus (Xen-30-12) showing the precise match between the dentition of $\mathrm{Ch}$. altifrontis and the marks on the vertebrae. Scale bar equals $10 \mathrm{~mm}$. 


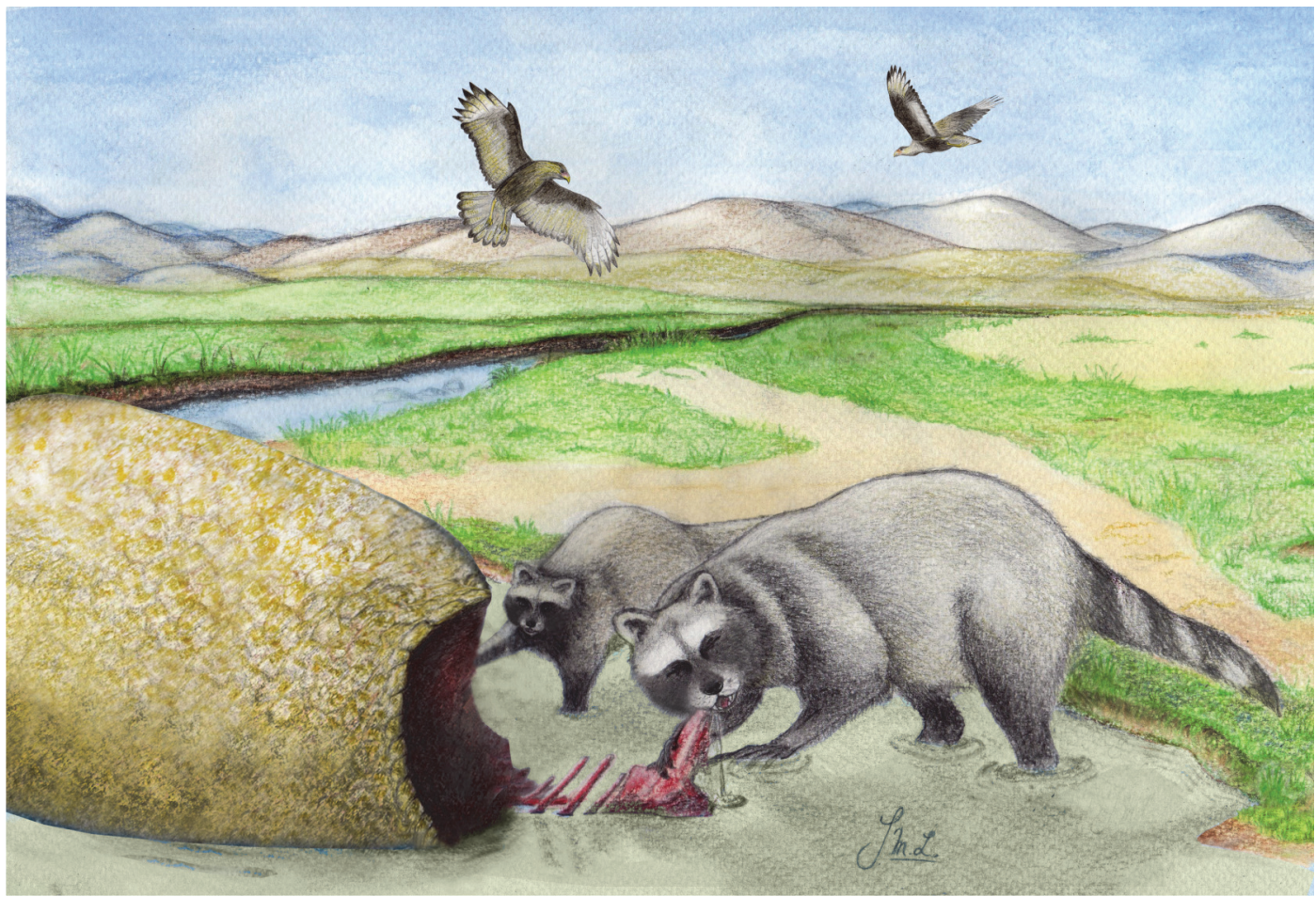

FIGURE 8. Reconstruction of the scene of consumption (By Luz Irrazábal).

shallow water body (i.e., an abandoned channel), where the carcass was covered and filled with sediments during, at least, four episodes (see above).

Approximately $30 \%$ of the anatomical parts of the carcass were found, without signals of considerable dispersion from their original anatomical position (except the piece Xen-30-12, which was located behind the synsacrum). The articulation of the left anterior stylopod and autopod, and the axis and atlas vertebrae, as well as the 0 state of weathering, are factors that reinforce the hypothesis of a relatively rapid burial, probably less than a year. In this lapse, the carcass still preserved soft tissues, tendons, and cartilage, including leather part (Behrensmeyer, 1978).

Due to the presence of bite marks in the material Xen-30-12, it is highly possible that the carcass was consumed by a carnivorous-scavenger taxon. While Delaney-Rivera et al. (2009) suggest that only a limited number of inferences can be observed in that concerning the size and taxonomic identification taking into account the dimensions of the tooth marks, our observations clearly suggest that the piece Xen-30-12 may correspond to a single bit event, probably produced by Chapalmalalania (Figure 8).

\section{ACKNOWLEDGEMENTS}

The authors wish to thank the company "Cementos Avellaneda S. A." to promote and support research in Paleontology and for allowing us the study the materials. The authors also thank Dr. E.P. Tonni for his helpful suggestions and D. Voglino for the drawings. This research was partially funded by grants PICT 1285, PI002-11.

\section{REFERENCES}

Alexander, R., Fariña, R.A., and Vizcaíno, S.F. 1999. Tail blow energy and carapace fractures in a large glyptodont (Mammalia, Edentata). Zoological Journal of the Linnean Society, 125:41-49.

Alonso-Zarza, A.M. 2003. Palaeoenvironmental significance of palustrine carbonates and calcretes in the geological record. Earth-Science Reviews, 60:261298.

Ameghino, F. 1888. Rápidas diagnosis de algunos mamíferos fósiles nuevos de la República Argentina. Editorial P.E. Coni, Buenos Aires, pp.1-17.

Ameghino, C. 1919. Sobre mamíferos fósiles del Piso Araucanense de Catamarca y Tucumán. $1^{\circ}$ Reunión Nacional de la Sociedad Argentina de Ciencias Naturales, Actas:151-152.

Behrensmeyer, A.K. 1978. Taphonomic and ecologic information from bone weathering. Paleobiology, 4:150-162. 
Berman, W.D. 1994. Los carnívoros continentales (Mammalia, Carnivora) del Cenozoico en la provincia de Buenos Aires. Unpublished Thesis, Facultad de Ciencias Naturales y Museo, Universidad Nacional de La Plata. Buenos Aires, Argentina.

Binford, L.R. 1981. Bones: Ancient Men and Modern Myths. Academic Press, New York..

Bond, M. 1986. Los ungulados fósiles de Argentina: evolución y paleoambientes. IV Congreso Argentino de Paleontología y Bioestratigrafía, Actas 2:173-185.

Borrello, A.V. 1966. Trazas, restos tubiformes y cuerpos fósiles problemáticos de la Formación La Tinta, Sierras Septentrionales de la Provincia de Buenos Aires. Paleontografía Bonaerense, Fasc. 5, Comisión de Investigaciones Científicas, Provincia de Buenos Aires, La Plata.

Cione, A.L. and Tonni, E.P. 1999. Biostratigraphy and chronological scale of upper-most Cenozoic in the Pampean Area, Argentina, p. 23-51. In Rabassa, J. and Salemme, M. (eds.), Quaternary of South America and Antarctic Peninsula. A.A. Balkema/Rotterdam/Brookfield.

Cione, A.L. and Tonni, E.P. 2005. Bioestratigrafía basada en mamíferos del Cenozoico Superior de la provincia de Buenos Aires, Argentina. $16^{\circ}$ Congreso Geológico Argentino, Relatorio:183-200.

Dalla Salda, L. and Iñiguez, A.M. 1979. La Tinta, Precámbrico y Paleozoico de Buenos Aires. $7^{\circ}$ Congreso Geológico Argentino, Actas 1:539-550.

Delaney-Rivera, C., Plummer, T.W., Hodgson, J.A., Forrest, F., Hertel, F., and Oliver, J.S. 2009. Pits and pitfalls: taxonomic variability and patterning in tooth mark dimensions. Journal of Archaeological Science, 36:2597-2608

Deschamps C.A., Vucetich M.G., Verzi D.H., and Olivares A.I. 2012. Biostratigraphy and correlation of the Monte Hermoso Formation (early Pliocene, Argentina): The evidence from caviomorph rodents. Journal of South American Earth Sciences, 35:1-9.

Dominato, V.H., Mothé, D., Costa da Silva, R., and dos Santos Avilla, L. 2011. Evidence of scavenging on remains of the gomphothere Haplomastodon waringi (Proboscidea: Mammalia) from the Pleistocene of Brazil: Taphonomic and paleoecological remarks. Journal of South American Earth Sciences, 31:171177.

Domínguez-Rodrigo, M. and Piqueras, A. 2003. The use of tooth pits to identify carnivore taxa in tooth-marked archaeofaunas and their relevance to reconstruct hominid carcass processing behaviours. Journal of Archaeological Science, 30:1385-1391.

Fernicola, J.C. 2008. Nuevos aportes para la sistemática de los Glyptodontia Ameghino 1889 (Mammalia, Xenarthra, Cingulata). Ameghiniana, 45:553-574.
Forasiepi, A., Goin, F., and Martinelli, A. 2009.Contribution to the knoweldge of the Sparassocynidae (Mammalia, Methatheria, Didelphoidea), with coments on the age of the Aisol Formation (Neogene), Mendoza province, Argentina. Journal of Vertebrate Paleontology, 29:1252-1263.

Forasiepi, A., Goin, F., and Tauber, A. 2004. Las especies de Arctodictis Mercerat, 1891 (Methatheria, Borhyaenidae), grandes carnívoros del Mioce de América del Sur. Revista Española de Paleontología, 19:1-22.

Forasiepi, A.M., Martinelli, A.G., and Goin, F. 2007. Taxonomic revision of Parahyaenodon argentinus Ameghino and its implicances for the Knowledge of the MioPliocene large carnivorous mammals of South America. Ameghiniana, 44:143-159.

Goin, F.J. 1995. Los Marsupiales, p. 163-180. In Alberdi, M.T., Leone, G., and Tonni, E.P. (eds.), Evolución biológica y climática de la región Pampeana durante los últimos cinco millones de años. Un ensayo de correlación con el Mediterráneo occidental. Monografías Museo Nacional de Ciencias Naturales, Consejo Superior de Investigaciones Científicas. Madrid, España.

Goin, F. J. and Pascual, R. 1987. News on the biology and taxonomy of the marsupials Thylacosmilidae (late Tertiary of Argentina). Anales de la Academia Nacional de Ciencias Exactas, Físicas y Naturales, 39:219-246, Buenos Aires.

Gilette, D.D. and Ray, C.E. 1981. Glyptodonts of North America. Smithsonian Contributions to Palaeobiology, 40:1-251.

Gray, J.E. 1869. Catalogue of carnivorous, pachydermatous and edentate Mammalia in the British Museum. London, British Museum (Natural History), VII + 398 pp.

Gutierrez, M.A. and Martínez, G. 2007. Trends in the faunal human exploitation during the late Pleistocene and early Holocene in the Pampean reion (Argentina). Quaternary International, 191:53-68. doi 10.1016/j.quaint.2007.09.

Huxley, T.H. 1864. On the osteology of the genus Glyptodon. Proceedings of the Royal Society of London 13:108 pp.

Illiger, C. 1811. Prodromus Systematis Mammalium et Avium Additis Terminis Zoographicis Utriusque Classis. xviii + 301 pages. Berlin. C. Salfeld.Kraglievich, J.L. and Olazábal, A.G. 1959. Los prociónidos extinguidos del género Chapalmalania Ameghino. Revista del Museo Argentino de Ciencias Naturales "Bernardino Rivadavia", Ciencias zoológicas, 6:1-59.

Marshall, L., Berta, A., Hoffstetter, R., Pascual, R., Reig, R., Bombin, M., and Mones, A. 1984. Mammals and stratigraphy: geochronology of the continental mammal-bearing Quaternary of South America: Palaeovertebrata, Mémoire Extraordinaire:1-76.

McKenna, M.C. and Bell, S.K. 1997. Classification of Mammals. Above the Species Level. Columbia University Press, New York. 
Miall, A.D. 1996. The Geology of Fluvial Deposits. Springer-Verlag, Berlin.

Nagera, J.J. 1940. Tandilia. Biblioteca de la Facultad de Humanidades y Ciencias de la. Educación, Universidad Nacional de La Plata, XXIV:1-272.

Palmqvist, P. and Vizcaíno, S.F. 2003. Ecological and reproductive constraints of body size in the gigantic Argentavis magnificens (Aves, Theratornithidae) from the Miocene of Argentina. Ameghiniana, 40: 379-385.

Paula Couto, J.C. 1979. Tratado de Paleomastozoología. Academia Brasileira de Ciências, Rio de Janeiro.

Poiré, D.G. 1993. Estratigrafía del Precámbrico sedimentario de Olavarría, Sierras Bayas, provincia de Buenos Aires, Argentina. $13^{\circ}$ Congreso Geológico Argentino y $3^{\circ}$ Congreso de Exploración de Hidrocarburos, Actas 2:1-11.

Poiré, D.G. 2009. Estratigrafía de la cobertura sedimentaria precámbrica/ paleozoica inferior de las Sierras Septentrionales de la provincia de Buenos Aires (Sistema de Tandilia), Argentina. Centro de Investigaciones Geológicas, Argentina.

Poiré, D.G., Canalicchio, J.M., de los Reyes, M., and. Prado, J.L. 2007. Estratigrafía de la cubierta terciaria/cuaternaria del Yacimiento El Polvorin, Olavarría, Sistema de Tandilia, Argentina. $6^{\circ}$ Jornadas Geológicas y Geofísicas Bonaerenses: 69.

Poiré, D.G., Canessa, N.D., Scillato-Yané, G.J., Carlini, A.A., Canalicchio, J.M., and Tonni, E.P. 2005. La Formación El Polvorín: una nueva unidad del Neogeno de Sierras Bayas, Sistema de Tandilia, Argentina. $16^{\circ}$ Congreso Geológico Argentino, Actas, I:315-322.

Politis, G., Johnson, E., Gutiérrez, M., and Hartwell, W. 2003. Survival of the Pleistocene fauna: New radiocarbon dates on organic sediments from La Moderna (Pampean region, Argentina), p. 45-50. In Miotti, L., Salemme, M., Flegenheimer, N., and Bonnichsen, R. (eds.), Where the South Winds Blow: Ancient Evidence for Paleo South Americans, Center for the Study of the First Americans, Texas University Press.

Prado, J.L., Cerdeño, E., and Roig-Juñent, S. 1998. The giant rodent Chapalmatherium from the Pliocene of Argentina: new remains and taxonomic remarks on the Family Hydrochoeridae. Journal of Vertebrate Paleontology, 18:788-798.

Saladie, P., Huguet, R., Díaz, C., Rodríguez-Hidalgo, A., and Carbonell E. 2011. Taphonomic modifications produced by modern brown bears (Ursus arctos). International Journal of Osteoarchaeology. Published online in Wiley Online Library. http://onlinelibrary.wiley.com/doi/10.1002/oa.1237/abstract
Schumm, S.A. 1977. The Fluvial System. Wiley, New York.

Selvaggio, M.M. and Wilder, J. 2001. Identifying the involvement of multiple carnivore taxa with archaeological bone assemblages. Journal of Archaeological Science, 28:465-470.

Soibelzon, L.H. 2007. Comentarios preliminares sobre la sistemática de los Procyonidae (Carnivora, Mammalia) fósiles de América del Sur. $6^{\circ}$ Jornadas Geológicas y Geofísicas Bonaerenses I:66.

Soibelzon, L.H. 2011. First description of milk teeth of fossil South American procyonid from the lower Chapadmalalan (Late Miocene-Early Pliocene) of "Farola Monte Hermoso" Argentina: paleoecological considerations. Paläontologische Zeitschrift, 85: 8389.

Soibelzon, L. and Prevosti, F. 2012. Fossils of South American land carnivores (Carnivora, Mammalia) capítulo 14, p. 509-530. In Ruiz, M. andShostell, J. (eds.), Molecular Population Genetics, Evolutionary Biology and Biological Conservation of Neotropical Carnivores. Nova Science Publisher, New York.

Woodburne, M.O. 2010. The Great American Biotic Interchange: dispersals, tectonics, climate, sea level and holding pens. Journal of Mammalian Evolution, 17:245-264.

Woodburne, M., Cione A.L., and Tonni, E.P. 2006. Central American provincialism and the Great American Biotic Interchange, p. 73-101. In CarranzaCastañeda, O. and Lindsay, E.H. (eds.), Advances in late Tertiary vertebrate paleontology in Mexico and the Great American Biotic Interchange. Universidad Nacional Autónoma de México, Instituto de Geología y Centro de Geociencias, Publicación Especial.

Zurita, A.E. 2007. Sistemática y evolución de los Hoplophorini (Xenarthra, Glyptodontidae, Hoplophorinae. Mioceno tardío-Holoceno temprano). Importancia bioestratigráfica, paleobiogeográfica y paleoambiental. Unpublished Thesis. Facultad de Ciencias Naturales y Museo, Universidad Nacional de La Plata, Buenos Aires, Argentina.

Zurita, A.E., Carlini, A.A., and Scillato-Yané, G.J. 2009. Paleobiogeography, biostratigraphy and systematics of the Hoplophorini (Xenarthra, Glyptodontoidea, Hoplophorinae) from the Ensenadan Stage (early Pleistocene to early-middle Pleistocene). Quaternary International, 210:82-92.

Zurita, A.E., Scarano, A., Carlini, A.A., Scillato-Yané, G.J., and Soibelzon, E. 2011. Neosclerocalyptus spp. (Cingulata: Glyptodontidae: Hoplophorini): cranial morphology and palaeoenvironments along the changing Quaternary. Journal of Natural History, 45:893-914. 